Article

\title{
Antecedents of Consumers' Intention to Purchase Energy-Efficient Appliances: An Empirical Study Based on the Technology Acceptance Model and Theory of Planned Behavior
}

\author{
Li Hua * and Shanyong Wang \\ School of Management, University of Science and Technology of China, No. 96, Jinzhai Road, Hefei 230026, \\ Anhui Province, China; wsy1988@mail.ustc.edu.cn \\ * Correspondence: hualini@mail.ustc.edu.cn
}

Received: 22 March 2019; Accepted: 21 May 2019; Published: 27 May 2019

check for updates

\begin{abstract}
Personal consumption behavior has negative impacts on the environment, such as climate change and wasted resources. To eliminate the adverse effects, more manufacturers are producing environmentally friendly products and governments are encouraging residents to adopt energy-saving products. Among these products, energy-efficient appliances are designed to save energy in everyday life. In this research, we focused on examining the antecedents of consumers' acceptance of energy-efficient appliances. A combined framework of the technology acceptance model and the theory of planned behavior was used. The research was empirically tested using an online survey of 280 consumers. The study indicates that perceived ease of use had a significant impact on perceived usefulness; moreover, it positively influenced consumers' attitudes. Subjective norms, perceived behavioral control, and attitude significantly affected consumers' purchasing intention. However, perceived usefulness did not have direct significant effect on consumers' purchasing intention. Furthermore, we conducted a comparative analysis to further analyze the effect of consumers' awareness of the China Energy Label on their purchasing intentions. Finally, insights and suggestions are discussed.
\end{abstract}

Keywords: energy-efficient appliances; technology acceptance model; theory of planned behavior; Energy Label; purchasing intention

\section{Introduction}

In recent years, along with rapid economic development, the Chinese government and citizens have also become concerned about the environment. China is one of the world's largest producers and consumers of household appliances. According to the statistics, during the last 20 years, the amounts of household appliances and other energy-intensive products have doubled [1]. According to statistics from the National Energy Administration, electricity consumption by urban and rural residents has increased continuously in the past few years. In 2010, the annual electricity consumption of rural and urban residents was 512.5 billion $\mathrm{kWh}$, and in 2016 this number increased sharply to 805.4 billion $\mathrm{kWh}$. It is worth nothing that household appliances are responsible for most of the energy consumption [2].

The rapid growth of household electrical appliances has led to a huge energy consumption, which worsens environmental pollution. Moreover, appliances that are not energy-efficient may waste electricity, which is not conducive to saving energy and reducing emissions [3]. Faced with severe ecological and environmental issues, promoting the use of energy-efficient appliances could help relieve the current serious situation. 
The Chinese government has paid a lot of attention to energy conservation. It published the China Energy Label regulation in August 2004 and implemented it in March 2005; the new edition of this regulation came into effect in June 2016. According to China Energy Label, there are five grades of energy efficiency: level 1 indicates that the appliance is at the international advanced level, that is and has the lowest energy consumption; whereas level 5 means that the appliance is the most power-hungry. In terms of the Chinese government's financial subsidy policy for energy-efficient appliances, appliances that are graded level 1 or 2 can be called energy-efficient.

Furthermore, the government has also proposed a series of incentive policies such as the national subsidy for energy-efficient appliances to popularize the use of such appliances and help achieve emission-reduction targets. In 2012, the government started a project to provide subsidies for five kinds of energy-saving products: air-conditioners, flat-screen televisions, refrigerators, washing machines, and water heaters, if they are graded at level 1 or 2 for energy efficiency. Generally, these policies stimulate consumers' demand for energy-efficient appliances.

Over several years of marketing, Chinese consumers have become more familiar with energy-efficient appliances. However, energy-efficient appliances have not gained a high market share in the whole Chinese appliance market. According to the Economic and Information Commission of Hunan Province, in 2014, the market share of energy-efficient appliances was only 5-15\% [4]. From the current sales status, it is apparent that the prices of energy-efficient appliances are higher than the prices of common appliances, sometimes several times the price. Many consumers do not think it is a good price/performance ratio, which lessens their enthusiasm for buying. Besides, some consumers are not confident in the benefits of new and advanced energy-efficient appliances, as the saving on electricity bills compared with the premium they need to pay is not a good deal. In addition, the outer materials, internal elements, and some other equipment of energy-efficient appliances are much better than those of common appliances, but consumers are not aware of these advantages. Hence the advantages of energy-efficient appliances do not help to grow sales.

At present, China has entered an important stage in which consumption plays a key role in economic growth, and new models such as green consumption have broad space and enormous potential for development. In 2016, the National Development and Reform Commission, Ministry of Science and Technology, and seven other departments issued "Guidance on Promoting Green Consumption". As suggested in the document, China plans to establish an effective long-term mechanism for green consumption by 2020, and the market share of green products will remarkably improve and consumers will be accustomed to a green, low-carbon, healthy lifestyle and consumption patterns. As for household appliances, the government wants to achieve the goal of more than $50 \%$ market share of energy-efficient appliances.

To advance the promotion of energy-efficient appliances, we wanted to know the factors that influence Chinese consumers' intention to purchase energy-efficient appliances. We used an integrated framework of the theory of planned behavior (TPB) and technology acceptance model (TAM) to understand consumers' purchasing intentions. TAM is a widely used model to study the acceptance of various technologies and TPB is regarded as one of the most useful frameworks to understand human behavior in many fields [5,6]. Given that energy-efficient appliances employ new and innovative technology to save electricity, it is reasonable to adopt TAM and TPB to understand consumers' purchasing intentions. By combining these two models, we tried to explore what factors could influence consumers' purchasing intentions and behaviors. A questionnaire survey for Chinese consumers was conducted online to collect the research data, and an analysis was made based on the structural equation model method. 


\section{Literature Review}

\subsection{Technology Acceptance Model}

The technology acceptance model (TAM) is a well-known theory put forward by Davis [7]. Davis's research mainly explored the influential and predominantly external variables that determine attitudes toward using technology. The research also looked at perceived usefulness and perceived ease of use, and Davis argued that these two belief factors determine the user's attitude toward technology, and that the attitude will affect behavioral intention, while perceived usefulness will directly influence intention. On the basis of identifying the relationships between perceived ease of use, perceived usefulness, attitude, and behavioral intention, we can get essential information of the target system.

\subsubsection{Perceived Ease of Use}

Perceived ease of use means that a specific system is believed to be simple and convenient to use for operators [7]. That is, if a person feels that a product is effortless to use in the process of executing a task, he or she may speak highly of it and tend to use it more [8]. Here, perceived ease of use is recognized as the extent to which people feel ease or not in the process of using a product. New technology is applied to energy-efficient appliances, which makes them different from common household appliances. Some consumers may get confused about such technological innovation and think the products are hard to use and tend to not use them. In a word, recognizing whether an item is easy to operate will affect consumers' intention to own it.

\subsubsection{Perceived Usefulness}

The definition of perceived usefulness (PU) is that one person is convinced that a specific system will help achieve great performance. [7]. It is the user's awareness of the improved work performance that technology can bring. Here, "usefulness" means that a product could help simplify work and increase accuracy [9]. It is quite evident that people usually tend to choose products that can reduce their working hours and improve work efficiency [10]. Perceived ease of use also has a positive influence on perceived usefulness [7]. That is, the difficulty of operating a new appliance may change people's opinions about it, because the harder it is to use, the more time and effort it will take, and this will reduce people's perception of usefulness. Here, perceived usefulness is related to the benefits that can be seen when using energy-efficient appliances. Energy-efficient appliances are aimed at reducing household electricity consumption so as to save energy and protect the environment. Hence, we speculate that consumers will be interested in energy-efficient appliances, as they are useful in trimming electric bills and enhancing quality of life.

\subsubsection{Attitude}

Attitude (ATT) means an individual's positive or negative view of a particular behavior [11]. It is concerned with judging the possible consequences of performing the behavior and will lead to different decisions based on different evaluations of the behavior. It reflects the positive or negative evaluation of one's perception of using the technology. Although energy-efficient appliances are generally believed to be helpful for environmental protection and ordinary life, people may still hold different views about them. If consumers have a positive attitude about energy-efficient appliances, they will probably purchase them; otherwise, they will have no interest.

\subsection{Theory of Planned Behavior}

The theory of planned behavior (TPB) was proposed by Fishbein and Ajzen [12]. It was adapted from the theory of reasoned action (TRA). Ajzen and Fishbein [11] posited that behavioral attitude and subjective norms were the most important factors of behavioral intention. In 1985, on the basis of the original viewpoint, Ajzen [13] added perceived behavioral control to the previous model. 
He believed that attitude, subjective norms, and perceived behavioral control jointly determined behavioral intention. Whether the target behavior occurs can be explained and predicted by a person's intention and the perceived behavior control. TPB is applied in a wide range of studies to explain how people behave in certain circumstances, e.g., individual consumption forecasting [14], online consuming behavior [15], and so on.

\subsubsection{Subjective Norms}

Subjective norm (SN) refers to people's cognition of the external stress over whether to perform a particular behavior. The stress mostly comes from individuals who matter a lot [11]. Here, subjective norms are related to external comments and opinions [16]. People will get information and evaluations from neighbors, relatives, and other intimate or prestigious people. According to the theory of reasoned action, people will tend to conform to social or general behavioral standards and regard pressure or expectations as part of the code of conduct. When people express views or choose actions, they can encounter pressure and judgment from the surroundings, especially people who are important to them [8]. In other words, individual behavior is related to the perception of social stress and reacting in a corresponding way. Park [17] pointed out that social pressure, such as subjective norms, was even more noticeable in the context of Chinese culture. When confronted with new things, Chinese consumers are more easily affected by others' words and actions and may change their initial intention. Thus, we propose that subjective norms will influence consumers' purchasing intentions.

\subsubsection{Perceived Behavioral Control}

The meaning of perceived behavioral control (PBC) can be expressed that a person makes judgements on the degree of difficulty in carrying out a particular action. [11]. In most cases, it depends on the availability of resources, such as the economic cost, effort, and time that individuals think they need to spend in the process of purchasing. Armitage and Conner $[18,19]$ suggested that there are two dimensions of perceived behavioral control: one is called "controllability," which describes consumers' perception of whether they can take control of their purchasing behavior in terms of available resources and opportunities. Someone who possesses more necessary resources will have a higher degree of controllability and therefore may feel more ease in performing an action. As for energy-efficient appliances, the "resource" is relevant to the economic capability of owning it, the ability to operate it smoothly, and other key factors, thus to some extent these traits are vital for consumers to make purchasing decisions [20]. Once the requirements of energy-efficient appliances are so high that they exceed consumers' acceptance or expectations, consumers may well give up on buying these products or turn to other goods. It is obvious that consumers are more likely to buy the appliances when they have high controllability in terms of owning and using the equipment [21]. In other words, individuals who have some relevant resources or more opportunities are more confident in having the control to perform the behavior and have higher purchasing intentions. Otherwise, they will have no interest in it.

As mentioned above, both perceived usefulness and perceived ease of use affect people's attitude toward accepting technology. At the same time, subjective norms and perceived behavioral control have a direct impact on behavioral intention. Thus, based on the combination of TAM and TPB, we obtained the basic model for this research (see Figure 1). Based on this model, we propose several hypotheses:

H1: Perceived ease of use has a positive impact on perceived usefulness.

H2: Perceived usefulness has a positive impact on consumers' attitudes toward energy-efficient appliances.

H3: Perceived ease of use has a positive impact on consumers' attitudes toward energy-efficient appliances.

H4: Perceived usefulness has a positive impact on consumers' intention to purchase energy-efficient appliances.

H5: Consumers' attitudes have a positive impact on their intentions to purchase energy-efficient appliances. 
H6: Subjective norms have a positive impact on consumers' intention to purchase energy-efficient appliances.

H7: Perceived behavioral control has a positive impact on consumers' intention to purchase energy-efficient appliances.

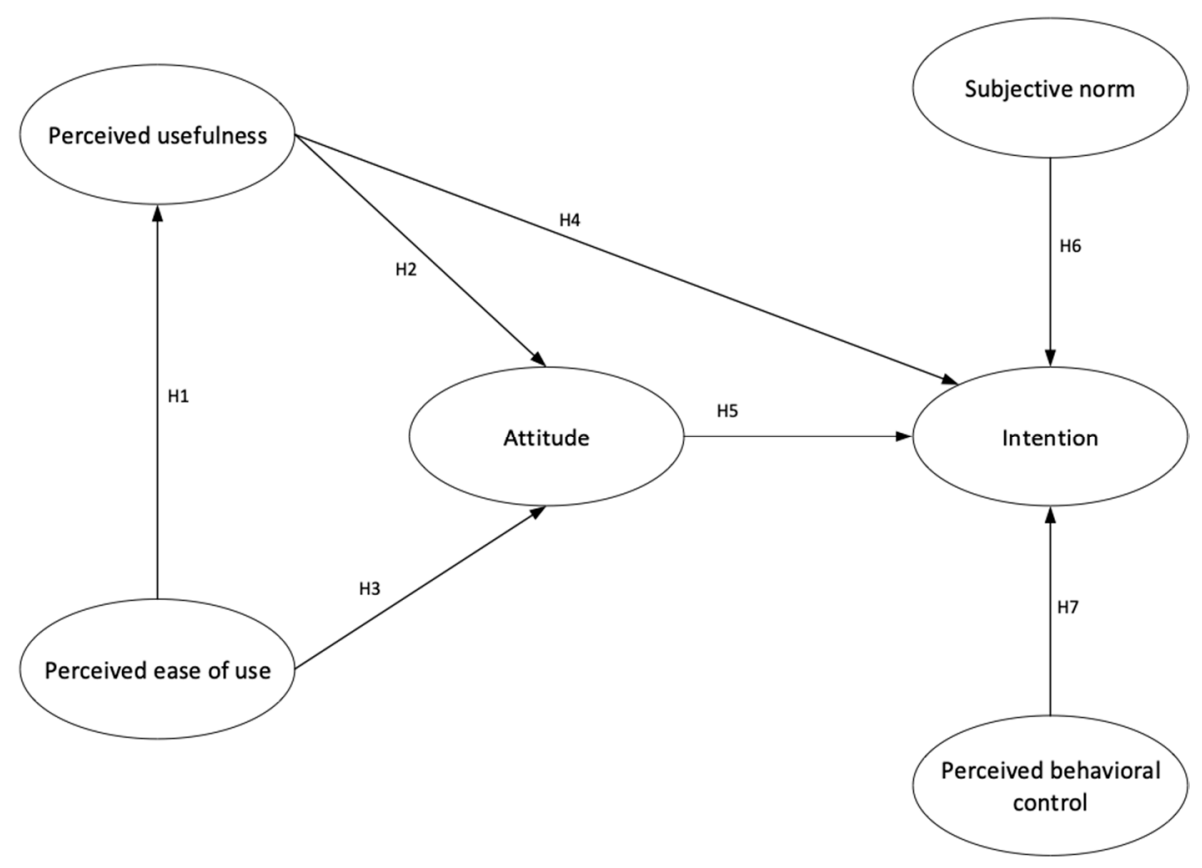

Figure 1. Hypothesis framework.

\section{Data and Method}

\subsection{Questionnaire Design and Data Collection}

Data for this study were collected using an online questionnaire survey in consideration of cost and data availability. On the basis of theoretical model and hypothesis framework, we designed the questionnaire. All constructs were measured with reference to previous research on green consumption behavior and acceptance of technology. To measure the items of TAM, we adapted from the research of Choi and Totten [22], and the items of TPB refer to Kim and Han [23] and Chan and Lau [24] (see Appendix A).

Except for the demographic variables, every item was used a 5-point Likert scale to match the degree to which respondents agreed with the items shown to them, ranging from 1, "strongly disagree," to 5, "strongly agree." In addition, we first asked the participants about their gender, age, educational level, and annual household income, and they were asked whether they knew the meaning and details of the China Energy Label.

$\mathrm{Wu}$ [25] pointed out that the sample size needs to be more than five times the number of measurement items. Furthermore, in order to get better results, the sample size should be at least 10 times larger than the number of measurement items. Hence, since there were 25 measurement items, the sample size should be at least 125 and preferably more than 250. In this study, 331 people responded to the questionnaire. After removing unqualified or incomplete responses, the final sample was decreased to 280 .

By the professional questionnaire platform Survey Star, we conducted the questionnaire survey, thus all the respondents have already registered on Survey Star. Generally speaking, the demographic characteristics of the respondents, such as gender and geographical location, roughly showed consistency with actual population profile of Chinese residents. Although there were some differences in age, educational level and annual household income from the demographic profile of Chinese 
residents, they were similar to the demographic data of Survey Star members [26]. Compared with Chinese residents, members of Survey Stars have the following traits: younger, richer and more educated [26], and internet users in China are mainly younger people. Hence, the sample of this survey had a better representativeness.

The respondents came from 20 provincial level administrative regions, covering all 7 geographical zones in China. Therefore, they represented almost the entire nation and varied hugely by background, profession, and income. Table 1 showed the demographic profile of the sample. The respondents mainly covered various consumer groups, which could be used for further analysis.

Table 1. Respondent profile.

\begin{tabular}{lcc}
\hline \multicolumn{1}{c}{ Demographic Variable } & Number & Percentage \\
\hline Gender & & \\
\hline Female & 192 & $68.57 \%$ \\
Male & 88 & $31.43 \%$ \\
\hline Age & & \\
\hline Under 18 & 5 & $1.79 \%$ \\
18-25 & 229 & $81.78 \%$ \\
$26-35$ & 42 & $15 \%$ \\
Above 35 & 4 & $1.43 \%$ \\
\hline Educational level & & \\
\hline Junior college and below & 87 & $31.07 \%$ \\
Bachelor's degree & 156 & $55.72 \%$ \\
Master's degree or above & 37 & $13.21 \%$ \\
\hline Annual household income & & \\
\hline Below 100,000 & 126 & $45 \%$ \\
100,000-150,000 & 104 & $37.14 \%$ \\
150,000-250,000 & 35 & $12.5 \%$ \\
Above 250,000 & 15 & $5.36 \%$ \\
\hline
\end{tabular}

As shown in Table 1, we obtained answers from 192 women and 88 men. Most of the respondents were between 18 and 25 years old, and about $55 \%$ had a bachelor's degree. The annual household income was concentrated around 100,000 RMB (1 USD = 6.71 RMB).

The ratio of male to female in China is about 104:100, and women are the main household appliance shoppers. According to data from Suning, one of the three major e-commerce platforms in China, women accounted for $62 \%$ of users who ordered household appliances during the Double Eleven period (internet shopping festival).

Among the survey respondents, the youngest was 17 years old and the oldest was 38 years old. According to the Statistical Report on the Development of Internet in China issued by the China Internet Information Center, by 2016, 87.4\% of Internet users were 10 to 49 years of age. Among them, people born in the 1990s accounted for $47 \%$, the largest group of netizens, and it was predicted that over the next few years users born in the 2000s will grow substantially. As we can see, internet users in China are relatively young as a whole.

In addition, in 2010, China carried out the sixth census and the results suggested that about $40 \%$ of the population was between 15 and 35. According to the report "Accenture's China Consumer Insight 2018: New Consumer Power," it was supposed that by 2017 there were about 700 million people between $18-35$ years of age, accounting for over $50 \%$ of the total population. China reached a fertility peak in the 1990s, thus when the younger generation starts to work and becomes of marriageable age, the demand for household appliances will increase. In 2013, Data of Consumption of China showed that young people who were born in the 1990s were becoming the mainstream consumer group in the household appliances market. Data from Baidu, Chinese top search engine, showed that post-90s 
consumers have become the main consumer force in the household appliances market and the target audience of household appliance manufacturers.

The majority of questionnaire respondents were aged from 18 to 25 years old and most of them were women, who make up the main force of the Chinese household appliances market. On this account, these respondents were representative and their intention to purchase energy-efficient household appliances is more in line with China's national conditions and has more practical significance. Paying attention to the consumption orientation of the younger generation can help in understanding the direction of promoting energy-saving household appliances in the future.

\subsection{Measurement Model}

In this study, we used confirmatory factor analysis (CFA) to test whether the relationship between a construct and the corresponding measurement items was consistent with the theoretical relationship designed by the researcher. To make sure that the effectiveness of the study is reasonable, we tested the reliability and construct validity. Reliability represents the consistency and stability of items under the same structure. Convergent validity and discriminant validity are subsets of construct validity. Convergent validity reflects the relationship of items under the same structure; discriminant validity shows significant differences between the characteristics of more than one construct.

According to the initial CFA results, the value of factor loading for item PEU1 was lower than 0.4, so we removed this indicator [27]. Then, with the help of SPSS v20.0 (IBM Corporation, New York, USA) statistical software, we tested the remaining items to determine the reliability of constructs. The Cronbach's alpha value for the six variables was $0.838,0.721,0.887,0.897,0.829$, and 0.771 , respectively, indicating that these constructs had good reliability [28]. Furthermore, the composite reliability (CR) of all constructs was greater than 0.7, meaning the questionnaire had good reliability [29].

As we can see from Table 2, all the factor loadings were higher than the standard 0.4 , and the average variance extracted (AVE) of each construct was also higher than the standard 0.5 , which indicated good convergent validity for the questionnaire according to Fornell and Larcker [30] Also, as Table 3 showed, the correlations between constructs of the model were less than the AVE square root values, which meant that the discriminant validity of all constructs was quite good [31].

Table 2. Reliability and validity estimates of measurement constructs.

\begin{tabular}{|c|c|c|c|c|c|}
\hline Construct & Indicator & Factor Loading & $\begin{array}{c}\text { Average Variance } \\
\text { Extracted (AVE) }\end{array}$ & $\begin{array}{c}\text { Composite } \\
\text { Reliability (CR) }\end{array}$ & $\begin{array}{l}\text { Cronbach's } \\
\text { Alpha }(\alpha)\end{array}$ \\
\hline \multirow{5}{*}{ PU } & 1 & 0.779 & \multirow{5}{*}{0.518} & \multirow{5}{*}{0.842} & \multirow{5}{*}{0.838} \\
\hline & 2 & 0.629 & & & \\
\hline & 3 & 0.763 & & & \\
\hline & 4 & 0.628 & & & \\
\hline & 5 & 0.781 & & & \\
\hline \multirow{3}{*}{ PEU } & 2 & 0.431 & \multirow{3}{*}{0.509} & \multirow{3}{*}{0.774} & \multirow{3}{*}{0.721} \\
\hline & 3 & 0.785 & & & \\
\hline & 4 & 0.852 & & & \\
\hline \multirow{5}{*}{ ATT } & 1 & 0.797 & \multirow{5}{*}{0.643} & \multirow{5}{*}{0.900} & \multirow{5}{*}{0.887} \\
\hline & 2 & 0.813 & & & \\
\hline & 3 & 0.861 & & & \\
\hline & 4 & 0.813 & & & \\
\hline & 5 & 0.721 & & & \\
\hline \multirow{5}{*}{ SN } & 1 & 0.689 & \multirow{5}{*}{0.618} & \multirow{5}{*}{0.888} & \multirow{5}{*}{0.897} \\
\hline & 2 & 0.831 & & & \\
\hline & 3 & 0.899 & & & \\
\hline & 4 & 0.889 & & & \\
\hline & 5 & 0.572 & & & \\
\hline
\end{tabular}


Table 2. Cont.

\begin{tabular}{cccccc}
\hline Construct & Indicator & Factor Loading & $\begin{array}{c}\text { Average Variance } \\
\text { Extracted (AVE) }\end{array}$ & $\begin{array}{c}\text { Composite } \\
\text { Reliability (CR) }\end{array}$ & $\begin{array}{c}\text { Cronbach's } \\
\text { Alpha }(\boldsymbol{\alpha})\end{array}$ \\
\hline \multirow{2}{*}{ PBC } & 1 & 0.890 & & & 0.833 \\
& 2 & 0.770 & 0.627 & & 0.829 \\
INT & 3 & 0.704 & & & 0.747 \\
& 1 & 0.807 & 0.502 & & 0.746 \\
\hline
\end{tabular}

Notes: PU: perceived usefulness; PEU: perceived ease of use; ATT: attitude; SN: subjective norms; PBC: perceived behavioral control; INT: intention.

Table 3. Correlation matrix.

\begin{tabular}{|c|c|c|c|c|c|c|c|}
\hline Construct & PU & PEU & ATT & SN & PBC & INT & Square Root of AVE \\
\hline PU & 1 & & & & & & 0.720 \\
\hline PEU & $0.34^{* *}$ & 1 & & & & & 0.713 \\
\hline ATT & $0.493^{* *}$ & $0.305^{* *}$ & 1 & & & & 0.803 \\
\hline SN & $0.192 * *$ & $0.124^{* *}$ & $0.142^{* *}$ & 1 & & & 0.786 \\
\hline PBC & $0.208^{* *}$ & $0.102 * *$ & $0.118^{* *}$ & $0.145^{* *}$ & 1 & & 0.792 \\
\hline INT & 0.162 & $0.211^{* *}$ & $0.515^{* *}$ & $0.298^{* *}$ & $0.323^{* *}$ & 1 & 0.709 \\
\hline
\end{tabular}

\subsection{Structural Equation Model}

The hypotheses were tested by means of structural equation modeling (SEM) with AMOS v22.0 (IBM Corporation, New York, USA). By using SEM, the unobservable variables can be explicated through some observable variables. Regarding sample size of SEM, Jackson [32] thought that the N:q rule could be used to roughly determine the number of samples required, where $\mathrm{N}$ is the number of samples and $\mathrm{p}$ is the parameter that needs to be estimated in the model. The recommended proportion is 20:1, and it can be relaxed to 10:1. Bentler end Chou [33] pointed out that the sample number and estimated parameters must have at least a 5:1 ratio to ensure that the estimated value of the parameter is credible, and the ratio should be at least 10:1 to ensure the validity of the significance test. Therefore, two studies recommended that 10:1 is the proportion to ensure good comparison. In a paper using SEM as an analytical method, Barrett [34] suggested that a sample volume of more than 200 was more appropriate, although this was not an absolute criterion.

Scuotto et al. [35] surveyed 175 companies using SEM to determine the key factors in their preference for informal inbound open innovation (OI). To explore the relationships among management, production and achievement of company, Yang et al. [36] surveyed 309 manufacturing enterprises and used structural equation modeling for analysis. Here, with the aid of AMOS, we established a structural equation model based on TAM and TPB to do research on 280 respondents.

After calculating the survey data of the model, AMOS output the results, and we found that some fitting indicators did not reach the criterion, which meant that the goodness of fit was not high and the model needed to be modified. Hence in light of suggestions from AMOS, we modified the initial model so that it would have a better fitting degree. Goodness of fit indices are as follows: X2/df $=2.079, \mathrm{GFI}=$ 0.891, NFI = 0.897, CFI = 0.943, IFI = 0.944, TLI = 0.924, RMSEA = 0.062 (GFI-goodness-of-fit index; NFI-normed fit index; CFI-comparative fit index; IFI-incremental fit index; TLI-Tucker-Lewis index; RMSEA - root-mean-square error of approximation). Most of the indicators meet the criterion, which means that the survey data match the theoretical framework well.

The results of hypothesis testing are listed in Table 4 . As we can see from Table 4, the relationship between perceived usefulness and intention is not significant. In addition, the results of other 
relationships are all significant, that is, these hypotheses passed the test. In short, hypotheses $\mathrm{H} 1, \mathrm{H} 2$, $\mathrm{H} 3, \mathrm{H} 5, \mathrm{H} 6$, and $\mathrm{H} 7$ are supported and $\mathrm{H} 4$ is not supported.

Table 4. Results of structural equation model and hypotheses testing.

\begin{tabular}{cccccc}
\hline & Path & & $\boldsymbol{\beta}$ & CR & p \\
\hline PU & $\leftarrow$ & PEU & 0.673 & 5.296 & $<0.001$ \\
ATT & $\leftarrow$ & PU & 0.693 & 7.935 & $<0.001$ \\
ATT & $\leftarrow$ & PEU & 0.383 & 2.336 & $<0.05$ \\
INT & $\leftarrow$ & PU & 0.103 & 1.393 & n.s. \\
INT & $\leftarrow$ & ATT & 0.660 & 5.650 & $<0.001$ \\
INT & $\leftarrow$ & SN & 0.372 & 2.035 & $<0.05$ \\
INT & $\leftarrow$ & PBC & 0.500 & 5.582 & $<0.001$ \\
\hline
\end{tabular}

Notes: C.R.: critical ratios for difference; n.s.: not significant.

\section{Results and Discussion}

\subsection{Analysis of Factors Affecting Energy-Efficient Appliance Purchase Intentions}

From Table 4, we can see that most of the hypotheses passed the test and only H4 is not supported.

First of all, the influence of perceived ease of use on perceived usefulness is significant and the beta coefficient is 0.673 . Energy-efficient appliances are new to consumers, so they will consider whether these products are easy to operate or not. If they think the appliances are difficult to use, they may evaluate these products as less useful. Perceived ease of use also has a significant influence on attitude. There is not much difference in appearance and main function between energy-efficient appliances and common appliances. After consumers get a rough understanding of energy-efficient appliances, they will see them as resembling ordinary appliances and tend to believe these products can be operated easily. When consumers think energy-efficient appliances are convenient to use, they will have a positive attitude toward them [37].

The beta coefficient of perceived usefulness on attitude is 0.693 , which is the largest. In daily life, a new product that is improved based on the original one will leave a better impression on consumers and, in turn, consumers will appreciate it [38]. Energy-efficient appliances are thought to be more useful, advanced, and innovative and can help deal with household chores better and provide greater service to reduce the heavy burden of housework so that consumers will prefer these new appliances.

Next, the effects of both perceived behavioral control and subjective norms on intention are significant. If consumers think they have enough money and ability to own and use energy-efficient appliances, they will be more willing to purchase them than people who lack adequate resources [39]. Meanwhile, China is a collectivist country and Confucian is the mainstream culture, therefore citizens are likely to be affected by the people around them and conformity is fairly common [40]. Once one person believes energy-efficient appliances are valuable, he or she will recommend them to others, and these people will be more inclined to buy the same products. Thus, consumers are often affected by social climate and tend to keep up with the people nearby. Meanwhile, attitude also has a significant influence on intention. It is apparent that when energy-efficient appliances are thought to be beneficial for daily life, consumers are prone to owning them to improve their quality of life.

Finally, the effect of perceived usefulness on intention is not significant. Although energy-efficient appliances are aimed at saving energy, they do not have a high price-performance ratio for consumers [41]. Compared with saving part of electricity bills, the prices of energy-efficient appliances are much higher than ordinary appliances, so the savings cannot compensate for the premium. There are more advantages of energy-efficient appliances, such as advanced outer materials and internal components, less machine noise, and so on, but these features are not highlighted to consumers. Thus, though consumers are acquainted with some of the benefits, these traits still lack enough power of persuasion to motivate consumers to purchase the product. Along with the unknown features, 
consumers may be hesitant to purchase because of uncertain benefits. In general, the perceived usefulness of energy-efficient appliances is not too attractive and there is not a strong desire to buy them.

\subsection{Effects of Energy Label Awareness}

McNeil and Wilkie [42] found that the Energy Label designation might have an impact on consumers' decision-making, which inspired other researchers to explore the influencing mechanism of the Energy Label. Since 1980, energy-saving behavior has drawn wide attention. In order to improve household energy efficiency, the Energy Label was designed for household appliances to provide consumers with information about saving energy. Mills and Sehleieh [43] found that the Energy Label affected consumers prominently in terms of purchasing appliances with higher energy-efficiency grades. The research of Zhou et al. [44] showed that the credibility of the Energy Label played a decisive role in improving consumers' perceived importance of the designation, and that consumers who knew about the Energy Label would be more willing to purchase energy-efficient appliances.

In China, the Energy Label Plan was launched in 2005. However, until 2012 only about $30 \%$ of Chinese consumers knew about it. Researchers reported that the physical information of the label was too hard for the general public to understand, which limited the popularization of the Energy Label [45].

Thus, awareness of the implications and contents of the Energy Label may influence the perception of energy-efficient appliances, and consumers' purchasing decisions may also be affected to some degree. Therefore, we divided the respondents into two groups based on whether or not they understood the Energy Label, then we compared their answers. In total, 166 respondents knew the meaning and details of the China Energy Label, and the remaining 114 respondents did not know. For the sake of convenience, we called the group that was not aware of the Energy Label NWEL and the other group WEL.

Table 5 presented the results from the two groups. As shown in the table, we found that the effect of perceived usefulness on intention was not significant in both groups. In WEL, subjective norms did not have a significant influence on intention, and perceived ease of use did not have a significant impact on attitude. The remaining relationships were all supported.

Table 5. Path coefficients between groups who were aware of the Energy Label (WEL) and not aware (NWEL).

\begin{tabular}{ccccccc}
\hline & \multirow{2}{*}{ Path } & & WEL & Significance & NWEL & \multicolumn{2}{c}{ Significance } \\
\cline { 3 - 6 } & & & $\boldsymbol{\beta}$ & $\boldsymbol{p}$ & $\boldsymbol{\beta}$ & $\boldsymbol{p}$ \\
\hline PU & $\leftarrow$ & PEU & 0.687 & $<0.001$ & 0.669 & $<0.001$ \\
ATT & $\leftarrow$ & PU & 0.699 & $<0.001$ & 0.699 & $<0.001$ \\
ATT & $\leftarrow$ & PEU & 0.081 & n.s. & 0.239 & $<0.05$ \\
INT & $\leftarrow$ & PU & 0.115 & n.s. & 0.124 & n.s. \\
INT & $\leftarrow$ & ATT & 0.634 & $<0.001$ & 0.666 & $<0.001$ \\
INT & $\leftarrow$ & SN & 0.007 & n.s. & 0.236 & $<0.05$ \\
INT & $\leftarrow$ & PBC & 0.316 & $<0.01$ & 0.557 & $<0.001$ \\
\hline
\end{tabular}

First, perceived usefulness did not have a significant impact on intention in both groups, which is consistent with the overall results and the explanation is similar. Next, the WEL group, as mentioned above, knew the contents of the Energy Label well, so that had a deeper understanding of the advantages of energy-efficient appliances. The research of Alban and Hutchinson [46] indicated that if consumers acquire enough information and knowledge, they will be less inclined to conform to what others are doing. Thus, their purchasing intentions will be more rational due to their awareness. Based on their awareness of energy-efficient appliances, they would subconsciously tend to prefer new and advanced products over traditional ones, and as a result, their cognition of energy-efficient appliances 
would matter more than other people's opinions, that is, subjective norms are not prominent with regard to consumers' buying intentions. On the contrary, lacking cognition about the function of energy-efficient appliances, consumers in the NWEL group tend to believe in the views of people around them, thus subjective norms have a significant effect on their buying intention.

For the WEL group, perceived ease of use did not have a significant influence on consumer attitudes. Previous research showed that relevant information could influence perceived ease of use [47]. The more efficient and adequate information consumers get, the better they will feel about ease of use. The Energy Label presents levels of energy efficiency, but there is nothing directly associated with ease of use. Even if consumers know about the Energy Label, they cannot get information from the label about whether the appliance is easy or difficult to operate. When the Energy Label is taken into consideration in the consumer's decision-making process, the label does not have a distinct effect. On the other hand, for the NWEL group, this relationship is significant. According to common sense and life experience, consumers who are not aware of the Energy Label will be more likely to assume that energy-efficient appliances are easier to use, thus they will have a positive attitude.

The Energy Label is a mark of authority and an essential certification for energy-efficient appliances, which is associated with the machine's working efficiency and power consumption [48]. In the current Chinese home appliances market, energy-efficient appliances are still at a stage that requires extensive promotion, and many citizens do not understand the Energy Label and care little about energy efficiency [49]. Thus, it is important to popularize information about the Energy Label.

\section{Conclusions and Implications}

\subsection{Conclusions}

Although energy-efficient appliances have been sold in the Chinese market for some years, they have not gained a high market share. Currently, the vast majority of the studies in China have focused on the role of government policy subsidies in stimulating consumers to buy energy-efficient appliances, but rarely has attention been paid to how the characteristics of energy-efficient appliances affect consumers' decision-making. Energy-efficient appliances are essentially consumer products, hence we explored their attraction to consumers from the perspective of taking them as new products with advanced energy-saving technology. With comprehensive consideration of their features and consumers' personal resources, we discuss the factors influencing the willingness to purchase energy-efficient appliances to enrich the relevant research and fill in the blanks.

In terms of theoretical research, the technology acceptance model, which is mainly applied in the field of information technology, has gradually expanded to other fields in recent years, such as research on asynchronous e-learning systems [50], smart appliances [8], electric vehicles [51], etc. In this study, through the analysis of energy-efficient appliances, the field of application for the technology acceptance model is expanded, reflecting its wide applicability. Besides, we further studied the impact of the Energy Label on consumers by making comparisons, and the results show that there were marked differences in the influence of certain factors on consumers of different groups, which provides a new perspective of thinking for follow-up research.

As far as current research is concerned, purchasing and using energy-efficient appliances are taken as energy-saving behaviors. In a survey of Canadian residents, Ritchie and Claxton [52] found that people's attitudes had no significant impact on their energy consumption behavior. In a survey of citizens in Washington State, Olsen [53] showed that gender had nothing to do with acceptability of energy-saving strategies. Curtis et al. [54] held the view that the amount of information people can use was positively correlated with their energy-saving activities, and if they realized that energy conservation could improve their personal interests and promote social progress, they would tend to choose energy-saving activities. Poortinga et al. [55] found that highlighting the practical benefits of technological innovation was the best way to drive consumers to adopt energy-saving behavior. 
Oikonomou et al. [56] pointed out that consumers want to reduce their cost of living by saving energy, so the key to changing consumer behavior was innovation in energy technology.

In a survey of residents in Hangzhou, China, Ouyang and Hoka [57] had the same view as Poortinga [55], emphasizing that technological innovation could bring real benefits to consumers and encourage them to engage in energy-saving activities. Liu [58] found that there were some problems in the energy-efficient appliances market, such as insufficient publicity of products, lack of knowledge of energy-efficient appliances, and manufacturers' inaccurate grasp of consumer demands. The research results of Deng et al. [59] showed that consumers' willingness to buy energy-efficient appliances was mainly based on considering their health, safety, and interests, rather than environmental awareness. Sun and Feng [60] found that consumers' attention to energy issues, the desire to reduce household expenditures, and the enhancement of normative awareness all contributed to the purchasing of energy-saving products. Mi et al. [61] found that social norms have a positive impact on consumers' awareness of energy conservation but do not play a significant role in choosing and purchasing energy-efficient appliances. Ma and Zhang [62] believed that information about energy conservation for the general public was still relatively scarce. The research of Wang et al. [63] discussed factors that influence Chinese residents' willingness to pay for energy-efficient appliances, and they focused on the impact of subsidy policy on consumption behavior. They developed a theory of planned behavior, and the results indicated that the policy environment and media propaganda did not have a significant influence on consumer decisions.

In this research, we tested the factors that influence the purchasing of energy-efficient appliances based on a combination of TAM and TPB. The results indicate that perceived ease of use influenced perceived usefulness and these two factors influenced consumers' attitude toward purchasing. Then subjective norms and perceived behavioral control had a positive effect on buying intention, which was similar to what was reported by Oikonomou et al. [56], Sun and Feng [60], and Mi et al. [61]. We found that consumers' attitudes affect their intentions; however, Ritchie and Claxton [52] reported that consumers' attitudes did not lead to actual behaviors, therefore the relationship between energy-saving attitudes, intentions, and behaviors needs to be further studied. We also found that the relationship between perceived usefulness and intention was not significant. Taking the domestic situation and previous findings into account, we can make sense of this result. Enough relevant information is important to consumers, and when they lack adequate and effective information on energy-efficient appliances, they are unable to make up their minds whether or not to purchase these products.

Furthermore, we divided the survey data into two groups to detect whether awareness of the Energy Label would influence consumers' attitudes and intentions. As the results suggest, in the WEL group, the relationships between perceived ease of use and attitude and between subjective norms and intentions were not significant, which was different from the results of the NWEL group. Except for these distinctions, the remaining relationships of the WEL group coincided with those of the NWEL group. Put in context, we found that people who were aware of the Energy Label knew more about energy-efficient appliances, including the pros and cons, so they were more inclined to make purchasing decisions according to effective information and rational judgment.

\subsection{Implications}

Based on the above results, we make the following proposals:

First of all, the market could improve at promoting energy-efficient appliances so that consumers believe they are worth the cost. As we mentioned before, the market share of energy-efficient appliances in China is not large. Some consumers think that the cost is too high relative to the performance of the machine, so they may refuse to pay too much for it. Thus, to improve the sales of energy-efficient appliances, sellers could focus on various advantages, which not only include lower energy consumption, but also longer service life, more comprehensive functional design, and so on.

Secondly, enterprises should focus more on consumers' needs for energy-efficient, such as providing clear and sufficient information about energy-efficient appliances to consumers in the 
process of choosing and purchasing products since enough and effective information is of great significance for their decision-making. Meanwhile, it is extremely important to inform consumers of professional content in a way that is easy to understand. Only with sufficient information, can they make the most rational and appropriate decision. Moreover, enterprises ought to take consumers' advices seriously to understand their demands for energy-efficient appliances. When designing and producing products, manufacturers should pay attention to the convenience and functionality in order to meet consumers' needs and make energy-efficient appliances more attractive.

Then, good images and nice comments from credible people and familiar surroundings should be used, since consumers are often influenced by friends, relatives, and people who are important to them. In the meantime, the development of social networks is very important and could be an appropriate channel in order to take full advantage of countrywide coverage of networks and social networking platforms to create and maintain a favorable image. In this way, consumers' purchasing intentions could be shared with other people and push them to be potential purchasers of energy-efficient appliances.

In addition, it is important to popularize the Energy Label and introduce related content to more consumers. Although the Energy Label has been in effect for 14 years many consumers still know little about it. Meanwhile, the government also needs to perfect the Energy Label continuously because the information that the label conveys can influence consumers' purchasing decisions. Therefore, the content and form of the Energy Label needs to be improved based on experts' opinions and consumers' feedbacks, so that it can be more practical and easier for consumers to understand. Furthermore, it is essential to draw on the mature experience of foreign countries and reasonable adjustments should be made in light of China's national conditions and residents' consumption habits.

In the long run, the government and corporations should promote scientific and technological innovation to produce more advanced energy-efficient appliances and reduce production cost. As the mastery of knowledge and skills will influence consumers' intention to purchase energy-efficient appliances, lowering the price and simplifying the operation of products could encourage consumers to buy these appliances. Then, consumers could get progressive products at relatively lower prices, in which case both manufacturers and consumers will receive benefits from the appliances.

\section{Limitations}

Along with a few interesting conclusions and implications in the research, some limitations should be noted. First, the study focused on purchasing intentions of consumers, while behaviors were not completely determined by intentions. Thus, future research could pay more attention to purchasing behaviors rather than intentions. In addition, due to time and cost constraints, the study sample was concentrated on young people, which may cause some deviation in the results. Although they are potentially the most active consumer group, expanding the types in the sample will make the conclusions more scientific and effective. Meanwhile, the sample size of this research was determined by the number of measurement items according to $\mathrm{Wu}[25]$ rather than statistical method, thus there was a limitation in sample size and we must admit that the results cannot be generalized. In further research, we will calculate the sample size based on appropriate statistical method to make the results more generally applicable. Finally, whether consumers understand that the Energy Label could influence their purchasing intentions to some extent, thus further research on the mechanism of how the Energy Label influences consumers' purchasing intentions is necessary.

Author Contributions: L.H. designed the framework of the paper with the help of Professor Wang, and L.H. wrote the paper. S.W. did text review and editing.

Funding: This research received no external funding.

Acknowledgments: My deepest gratitude goes first and foremost to Shanyong Wang, for his consistent and illuminating instruction and guidance. Then I want to thank my friends for helping with my language and writing, and their continuous encouragement and supports.

Conflicts of Interest: The authors declare no conflict of interest. 


\section{Appendix A}

Table A1. Measurement scales for constructs.

\begin{tabular}{|c|c|c|}
\hline Construct & Indicator & Measurement Items \\
\hline \multirow{5}{*}{ Perceived Usefulness } & PU1 & $\begin{array}{l}\text { I think using energy-efficient appliances can save } \\
\text { energy and protect the environment. }\end{array}$ \\
\hline & PU2 & $\begin{array}{l}\text { I think the working efficiency of energy-efficient } \\
\text { appliances is higher than that of common appliances. }\end{array}$ \\
\hline & PU3 & $\begin{array}{l}\text { I think using energy-efficient appliances can reduce } \\
\text { my electricity bill. }\end{array}$ \\
\hline & PU4 & $\begin{array}{l}\text { I think using energy-efficient appliances can help me } \\
\text { improve my quality of life. }\end{array}$ \\
\hline & PU5 & In other words, energy-efficient appliances are useful. \\
\hline \multirow{4}{*}{ Perceived Ease of Use } & PEU1 & $\begin{array}{l}\text { I think there is not much difference between } \\
\text { energy-efficient appliances and common appliances. }\end{array}$ \\
\hline & PEU2 & $\begin{array}{l}\text { I think it is easy to operate energy-efficient } \\
\text { appliances. }\end{array}$ \\
\hline & PEU3 & $\begin{array}{l}\text { I think the function of energy-efficient appliances is } \\
\text { not complicated. }\end{array}$ \\
\hline & PEU4 & $\begin{array}{l}\text { In other words, energy-efficient appliances are easy } \\
\text { for me to use. }\end{array}$ \\
\hline \multirow{5}{*}{ Subjective Norms } & SN1 & It is pleasing to have energy-efficient appliances. \\
\hline & SN2 & $\begin{array}{l}\text { If respectable or important people use } \\
\text { energy-efficient appliances, I would like to use them } \\
\text { more. }\end{array}$ \\
\hline & SN3 & $\begin{array}{l}\text { If my family and friends use energy-efficient } \\
\text { appliances, I would like to use them more. }\end{array}$ \\
\hline & SN4 & $\begin{array}{l}\text { If people around me use energy-efficient appliances, I } \\
\text { would like to use them more. }\end{array}$ \\
\hline & SN5 & Using energy-efficient appliances is a social trend. \\
\hline \multirow{5}{*}{ Attitude } & ATT1 & I look forward to using energy-efficient appliances. \\
\hline & ATT2 & I like to use energy-efficient appliances. \\
\hline & ATT3 & $\begin{array}{l}\text { I have a positive attitude toward using } \\
\text { energy-efficient appliances. }\end{array}$ \\
\hline & ATT4 & $\begin{array}{l}\text { I think using energy-efficient appliances is good for } \\
\text { my life. }\end{array}$ \\
\hline & ATT5 & $\begin{array}{l}\text { I would like to recommend energy-efficient } \\
\text { appliances to people around me. }\end{array}$ \\
\hline \multirow{3}{*}{$\begin{array}{l}\text { Perceived Behavioral } \\
\text { Control }\end{array}$} & PBC1 & $\begin{array}{l}\text { My family has a good grasp of new functions of } \\
\text { energy-efficient appliances. }\end{array}$ \\
\hline & PBC2 & $\begin{array}{l}\text { My family has enough income to own } \\
\text { energy-efficient appliances. }\end{array}$ \\
\hline & PBC3 & $\begin{array}{l}\text { My family could deal with problems in the use of } \\
\text { energy-efficient appliances and solve them. }\end{array}$ \\
\hline \multirow{3}{*}{ Intention } & INT1 & $\begin{array}{l}\text { In the future, I will buy energy-efficient appliances if } \\
\text { I need to have home appliances. }\end{array}$ \\
\hline & INT2 & $\begin{array}{l}\text { In the future, I am willing to pay higher prices for } \\
\text { energy-efficient appliances. }\end{array}$ \\
\hline & INT3 & $\begin{array}{l}\text { In the future, I plan to buy appliances with better } \\
\text { energy efficiency. }\end{array}$ \\
\hline
\end{tabular}

\section{References}

1. Lobo, A.; Greenland, S. Pro-environmental purchase behaviour: The role of consumers' biospheric values. J. Retail. Consum. Serv. 2016, 33, 98-108. 
2. Xu, L. Subsidy and energy efficiency standard to promote energy-efficient appliances. Ind. Track. 2010, 9, 54-56. (In Chinese)

3. Yadav, R.; Pathak, G.S. Determinants of consumers' green purchase behavior in a developing nation: Applying and extending the theory of planned behavior. Ecol. Econ. 2017, 134, 114-122. [CrossRef]

4. Zhang, H.Z. The market share of energy-efficient household appliances is less than $15 \%-$ Hunan province has completed the third batch of promotion information verification of energy-efficient appliances of Huimin Project. Changsha Evening Newspaper, 13 January 2014. (In Chinese)

5. Agarwal, R.; Prasad, J. Are individual differences germane to the acceptance of new information technologies? Decis. Sci. 1999, 30, 361-392. [CrossRef]

6. Stern, P.C. Understanding individuals' environmentally significant behavior. Environ. Law Rep. News Anal. 2005, 35, 1-10.

7. Davis, F.D. Perceived usefulness, perceived ease of use, and user acceptance of information technology. MIS Q. 1989, 13, 319-342. [CrossRef]

8. Toft, M.D.; Schuitema, G.; Thøgersen, J. Responsible technology acceptance: Model development and application to consumer acceptance of Smart Grid technology. Appl. Energy 2014, 134, 392-400. [CrossRef]

9. Venkatesh, V. Determinants of perceived ease of use: Integrating control, intrinsic motivation, and emotion into the technology acceptance mode. Inf. Syst. Res. 2000, 11, 342-365. [CrossRef]

10. Bhattacherjee, A. An empirical analysis of the antecedents of electronic commerce service continuance. Decis. Support Syst. 2001, 32, 201-214. [CrossRef]

11. Fishbein, M.; Ajzen, I. Understanding Attitudes and Predicting Social Behavior; Prentice-Hall, Inc.: Englewood Cliffs, NJ, USA, 1980.

12. Fishbein, M.; Ajzen, I. Belief, Attitude, Intention, and Behavior: An Introduction to Theory and Research; Addison-Wesley: Reading, MA, USA, 1975; pp. 234-243.

13. Ajzen, I. From intentions to actions: A theory of planned behavior. In Action Control: From Cognition to Behavior; Kuhl, J., Beckman, J., Eds.; Springer: Heidelberg, Germany, 1985; pp. 11-39.

14. Liu, Y.W. An integrated model of behavior of China's green consumers based on TPB. China Bus. Market 2008, 22, 66-69. (In Chinese)

15. Lim, H.; Dubinsky, A.J. Consumers' perceptions of e-shopping characteristics: Expectancy-value approach. J. Serv. Mark. 2004, 18, 500-513. [CrossRef]

16. Kaushik, A.K.; Rahman, Z. An alternative model of self-service retail technology adoption. J. Serv. Mark. 2015, 29, 406-420. [CrossRef]

17. Park, H.S. Relationships among attitudes and subjective norm: Testing the theory of reasoned action across cultures. Commun. Stud. 2000, 51, 162-175. [CrossRef]

18. Armitage, C.J.; Conner, M. The theory of planned behavior: Assessment of predictive validity and "Perceived Control". Br. J. Soc. Psychol. 1999, 38, 35-54. [CrossRef]

19. Armitage, C.J.; Conner, M. Distinguishing perceptions of control from self-efficacy: Predicting consumption of a low-fat diet using the theory of planned behavior. J. Appl. Soc. Psychol. 2006, 29, 72-90. [CrossRef]

20. Lindenberg, S.; Steg, L. Normative, gain and hedonic goal frames guiding environmental behavior. J. Soc. Issues 2007, 63, 117-137. [CrossRef]

21. Hui, M.K.; Bateson, J.E.G. Perceived control and the effects of crowding and consumer choice on the service experience. J. Consum. Res. 1991, 18, 174-184. [CrossRef]

22. Choi, Y.K.; Totten, J.W. Self-construal's role in mobile TV acceptance: Extension of TAM across cultures. J. Bus. Res. 2012, 65, 1525-1533. [CrossRef]

23. Kim, Y.; Han, H. Intention to pay conventional-hotel prices at a green hotel-A modification of the theory of planned behavior. J. Sustain. Tour. 2010, 18, 997-1014. [CrossRef]

24. Chan, R.Y.K.; Lau, L.B.Y. Explaining green purchasing behavior: A cross cultural studies on American and Chinese consumers. J. Int. Consum. Mark. 2002, 14, 9-40. [CrossRef]

25. Wu, M.L. Questionnaire Statistical Analysis Practice-SPSS Operation and Application; Chongqing University Press: Chongqing, China, 2010.

26. Shi, G.H. Behaviors of Weibo Use Predict the Big-Five Personality Traits. Master's Thesis, Central China Normal University, Wuhan, China, 2014.

27. Ford, J.K.; MacCallum, R.C.; Tait, M. The applications of exploratory factor analysis in applied psychology: A critical review and analysis. Pers. Psychol. 1986, 39, 291-314. [CrossRef] 
28. Nunnally, J.C. Psychometric Theory; McGraw-Hill: New York, NY, USA, 1978.

29. Bagozzi, R.P.; Yi, Y. On the evaluation of structural equation models. J. Acad. Mark. Sci. 1988, 16, 74-94. [CrossRef]

30. Fornell, C.; Larcker, D.F. Structural equation models with unobservable variables and measurement error: Algebra and statistics. J. Mark. Res. 1981, 18, 382-388. [CrossRef]

31. Chin, W.W.; Gopal, A.; Salisbury, W.D. Advancing the theory of adaptive structuration: The development of a scale to measure faithfulness of appropriation. Inf. Syst. Res. 1997, 8, 342-367. [CrossRef]

32. Jackson, D.L. Revisiting sample size and number of parameter estimates: Some support for the N: Q hypothesis. Struct. Equ. Model. 2003, 10, 128-141. [CrossRef]

33. Bentler, P.M.; Chou, C.P. Practical issues in structural modeling. Sociol. Methods Res. 1987, 16, 78-117. [CrossRef]

34. Barrett, P. Structural equation modelling: Adjudging model fit. Pers. Individ. Differ. 2007, 42, 815-824. [CrossRef]

35. Scuotto, V.; Del Giudice, M.; Bresciani, S.; Meissner, D. Knowledge-driven preferences in informal inbound open innovation modes. An explorative view on small to medium enterprises. J. Knowl. Manag. 2017, 21, 640-655. [CrossRef]

36. Yang, M.G.; Hong, P.; Modi, S.B. Impact of lean manufacturing and environmental management on business performance: An empirical study of manufacturing firms. Int. J. Prod. Econ. 2011, 129, 251-261. [CrossRef]

37. Belanche, D.; Casaló, L.V.; Flavián, C. Integrating trust and personal values into the technology acceptance model: The case of e-government services adoption. Cuadernos de Economía y Dirección de la Empresa 2012, 15, 192-204. [CrossRef]

38. Olsen, M.C.; Slotegraaf, R.; Chandukala, S.R. Green Claims and Message Frames: How Green New Products Change Brand Attitude. J. Mark. 2014, 78, 119-137. [CrossRef]

39. Paul, J.; Modi, A.; Patel, J. Predicting green product consumption using the theory of planned behavior and reasoned action. J. Retail. Consum. Serv. 2016, 29, 123-134. [CrossRef]

40. Li, J.J.; Su, C. How face influence consumption: A comparative study of American and Chinese consumers. Int. J. Market Res. 2007, 49, 237-256.

41. Feng, D.; Socacol, B.K.; Vu, K.M. The barriers to energy efficiency in China: Assessing household electricity saving and consumer behavior in Liaoning Province. Energy Policy 2010, 38, 1202-1209.

42. McNeil, D.L.; Wilkie, W.L. Public policy and consumer information: Impact of the new Energy Labels. J. Consum. Res. 1979, 6, 154-165. [CrossRef]

43. Mills, B.; Sehleieh, J. What's driving energy-efficient appliance label awareness and purchase propensity? Energy Policy 2010, 38, 814-825. [CrossRef]

44. Zhou, D.P.; Wang, L.L.; Lv, W. Research on integrated psychological model of consumer adoption of Energy-efficiency Label. Soft Sci. 2017, 31, 123-128. (In Chinese)

45. Yu, Z.N.; Wang, L.L.; Zhou, D.P. Research on the effectiveness of social norm information of energy efficiency label of energy-efficient appliances in China. Shanghai Manag. Sci. 2017, 39, 97-103. (In Chinese)

46. Alban, J.W.; Hutchinson, J.W. Knowledge calibration: What consumers know and what they think they know. J. Consum. Res. 2000, 27, 123-156. [CrossRef]

47. Koufaris, M.; Hampton-Sosa, W. The development of initial trust in an online company by new customers. Inf. Manag. 2004, 41, 377-397. [CrossRef]

48. Truffer, B.; Markard, J.; Wustenhagen, R. Eco-labeling of electricity—Strategies and tradeoffs in the definition of environmental standards. Energy Policy 2001, 29, 885-897. [CrossRef]

49. Teisl, M.F.; Roe, B.; Hicks, R.L. Can eco-labels tune a market? Evidence from dolphin-safe labeling. J. Environ. Econ. Manag. 2002, 43, 339-359. [CrossRef]

50. Ong, C.S.; Lai, J.Y.; Wang, Y.S. Factors affecting engineers' acceptance of asynchronous e-learning systems in high-tech companies. Inf. Manag. Amster. 2004, 41, 795-804. [CrossRef]

51. Tang, Y. Factors that Influence the Acceptance of Small Electric Car Based on TAM. Master's Thesis, Huazhong University of Science and Technology, Wuhan, China, 2014.

52. Ritchie, B.G.; Claxton, M.J. Complexities of household energy consumption and conservation. J. Consum. Res. 1981, 8, 233-242. [CrossRef]

53. Olsen, M. Public acceptance of consumer energy conservation strategies. J. Econ. Psychol. 1983, 4, $183-196$. [CrossRef] 
54. Curtis, F.; Simpson-Housley, P.; Dtever, S. Household energy conservation. Energy Policy 1984, 12, 452-456. [CrossRef]

55. Poortinga, W.; Steg, L.; Vlek, C.; Wiersma, G. Household preferences for energy-saving measures: A conjoint analysis. J. Econ. Psychol. 2003, 24, 49-64. [CrossRef]

56. Oikonomou, V.; Becchis, F.; Steg, L.; Russolillo, D. Energy saving and energy efficiency concepts for policy making. Energy Policy 2009, 37, 4787-4796. [CrossRef]

57. Ouyang, J.L.; Hoka, K. Energy-saving potential by improving occupants behavior in urban residential sector in Hangzhou City, China. Energy Build. 2009, 41, 711-720. [CrossRef]

58. Liu, Y. Problems and Countermeasures in energy-efficient appliances consumption: Based on the investigation and analysis of Jinan household appliances market. Market Mod. 2010, 8, 115-116. (In Chinese)

59. Deng, Q.; Huang, Q.F.; Wang, Q. Public sense on home appliance consumption and attitude to waste home appliance recycling: A case study in Qingdao. Recycl. Resour. Circ. Econ. 2010, 1, 41-44. (In Chinese)

60. Sun, Y.; Feng, L.F. Influence of psychological, family and contextual factors on residential energy use behavior: An empirical study of China. Energy Procedia 2011, 5, 910-915.

61. Mi, L.Y.; Nie, R.; Li, H.L.; Li, X.H. Empirical research of social norms affecting urban residents low carbon energy consumption behavior. Energy Procedia 2011, 5, 229-234.

62. Ma, G.; Zhang, J.D. Study on Chinese consumer attitudes on energy-saving household appliances and government policies: Based on a questionnaire survey of residents in Chongqing China. Energy Procedia 2011, 5, 445-451. [CrossRef]

63. Wang, Z.H.; Wang, X.M.; Guo, D.X. Policy implications of the purchasing intentions towards energy-efficient appliances among China's urban residents: Do subsidies work? Energy Policy 2017, 102, 430-439. [CrossRef]

(C) 2019 by the authors. Licensee MDPI, Basel, Switzerland. This article is an open access article distributed under the terms and conditions of the Creative Commons Attribution (CC BY) license (http://creativecommons.org/licenses/by/4.0/). 